\title{
PERSEPSI DAN MOTIVASI DIGITAL NOMAD BERWISATA DI DESA TIBUBENENG, CANGGU, KUTA UTARA
}

\author{
Cipta Mulyana $^{1}$, I Putu Sudana ${ }^{2}$, Putu Agus Wikanatha Sagita ${ }^{3}$ \\ Email: ciptahutagalung@gmail.com¹, sudanaputu@yahoo.com², wika.fpar@gmail.com \\ ${ }^{1,2,3}$ Program Studi Industri Perjalanan Wisata, Fakultas Pariwisata, Universitas Udayana
}

\begin{abstract}
Bali as an international tourism destination has many tourist attractions, one of which is Canggu. In 2018 nomadlist.com released that Canggu was chosen as the best destination for digital nomads. A new tourist trend has emerged where tourists who work outside the office and complete their work using electronic media such as laptops and internet connections in a coworking space and conduct tourism activities called digital nomads. This research was conducted to determine the Perceptions and Motivations of Digital Nomad travelling in Tibubeneng Village, Canggu village, Badung Regency, Bali. This research was conducted by using questionnaires to digital nomad in several coworking spaces in Tibubeneng Village, Canggu, in addition to distributing questionnaires to the nomads conducted open observation and interviews with several nomads and coworking space staff to complete the data.The results showed that the majority of digital nomads visiting Tibubeneng Village, Canggu were from Australia and Europe, most of whom worked as entrepreneurs. The indicator on the perception that gets the highest score is hospitality from the digital nomad while the indicator that gets the lowest response is the road conditions to Tibubeneng Village, Canggu. On the motivation indicator, physical motivation gets the highest score from a digital nomad while the motivation with the lowest score is showing prestige.
\end{abstract}

Abstrak: Sebagai destinasi pariwisata internasional Bali mempunyai banyak daya tarik wisata, salah satunya adalah Canggu. Pada tahun 2018 nomadlist.com merilis Canggu sebagai destinasi nomer satu di dunia bagi digital nomad. Tren wisatawan baru muncul dimana wisatawan yang bekerja diluar kantor dan menyelesaikan pekerjaanya menggunakan media elektronik berupa laptop dan koneksi internet disebuah coworking space dan melakukan kegiatan wisata disebut digital nomad. Penelitian ini dilakukan untuk mengetahui persepsi dan motivasi digital nomad berwisata di Desa Tibubeneng, Canggu Kabupaten Badung Bali. Penelitian ini dilakukan dengan menggunakan penyebaran kuisioner kepada digital nomad di beberapa coworking space yang ada di Desa Tibubeneng, Canggu, selain penyebaran kuisioner kepada digital nomad dilakukan observasi dan wawancara terbuka dengan beberapa digital nomad dan staff coworking space untuk melengkapi data. Hasil penelitian menunjukan bahwa digital nomad yang berkunjung ke Desa Tibubeneng, Canggu mayoritas berasal dari Australia dan Eropa yang kebanyakan berprofesi sebagai seorang pengusaha. Indikator pada persepsi yang mendapatkan nilai tertinggi adalah hospitality sedangkan indikator yang mendapat respon terendah adalah kondisi jalan menuju Desa Tibubeneng, Canggu. Pada indikator motivasi, motivasi fisik mendapat skor tertinggi dari digital nomad sedangkan motivasi dengan nilai terendah adalah menunjukan gengsi.

Keywords: coworking space, digital nomad, motivasi, persepsi.

\section{PENDAHULUAN}

Pariwisata adalah sektor unggulan nonmigas yang menghasilkan devisa bagi Indonesia, semakin banyak wisatawan yang berkunjung ke Indonesia maka akan semakin banyak devisa yang dihasilkan begitu pula sebaliknya. Sebagai negara kepulauan Indonesia mempunyai keanekaragaman suku dan budaya yang terbentang dari ujung barat sabang sampai ke ujung timur merauke. Salah satu destinasi pariwisata andalan Indonesia adalah Pulau Bali. Bali menjadi tujuan utama wisatawan karena keindahan alam dan budayanya. Salah satu kabupaten yang mempunyai industri pariwisata yang baik adalah kabupaten Badung, beberapa kawasan yang telah dikenal dan banyak dikunjungi wisatawan seperti Kuta, Seminyak, Uluwatu, 
dan Canggu terletak di Kabupaten Badung, ini disebabkan kawasan tersebut memiliki infrastruktur dan akses yang baik dan mudah diakses oleh wisatawan, selain itu kawasan tersebut juga terletak tidak jauh dengan Bandara Internasional I Gusti Ngurah Rai. Sebagai destinasi pariwisata internasional Bali telah banyak dikenal dan dikunjungi oleh wisatawan internasional.

Salah satu kawasan yang mulai banyak dikunjungi oleh wisatawan adalah Desa Tibubeneng, Canggu yang terletak di Kecamatan Kuta Utara, Kabupaten Badung. Terletak di Kecamatan Kuta Utara, Desa Tibubeneng, Canggu berada dekat dengan kawasan Seminyak dan Kuta yang terlebih dahulu banyak dikunjungi oleh wisatawan sebelumnya, hal ini membuat Desa Tibubeneng, Canggu mudah diakses oleh wisatawan, selain itu akses jalan menuju Desa Tibubeneng, Canggu sudah cukup baik sehingga wisatawan dapat mengakses kendaraan bermotor seperti mobil ataupun sepeda motor menuju Desa Tibubeneng, Canggu. Setelah mengalami perkembangan yang baik dan banyak dikunjungi oleh wisatawan, diakhir tahun 2018 website nomadlist.com merilis Canggu sebagai destinasi terfavorit bagi digital nomad di dunia dan mendapatkan nomad score paling tinggi yaitu 5 dari skala tertinggi 5 dibandingkan kota lainnya, untuk melihat nomad score setiap destinasi dapat dilihat pada tabel 1 berikut.

Tabel 1. Data Nomad Score

\begin{tabular}{clc}
\hline No & \multicolumn{1}{c}{ Destinasi } & Score \\
\hline 1 & Canggu, Indonesia & 5 \\
\hline 2 & Bangkok, Thailand & 4,62 \\
\hline 3 & Chiang Mai, Thailand & 4,54 \\
\hline 4 & Budapest, Hungary & 4,5 \\
\hline 5 & Seoul, South Korea & 4,43 \\
\hline 6 & Berlin, Germany & 4,42 \\
\hline 7 & Belgrade, Serbia & 4,33 \\
\hline 8 & Taipe, Taiwan & 4,14 \\
\hline 9 & Sofia, Bulgaria & 4,09 \\
\hline 10 & Buenos Aires, Argentina & 4,05 \\
\hline
\end{tabular}

Sumber: Nomadlist, 2019.

Berdasarkan tabel 1, dapat kita lihat bahwa Canggu mendapatkan nomad score tertinggi yaitu 5 dibandingkan negara lainnya. Nomadlist.com adalah sebuah website bagi digital nomad untuk mendapatkan informasi yang berisi database lebih dari 2.344 kota di dunia yang membantu digital nomad untuk mengunjungi suatu tempat (nomadlist.com). Dikutip dari salah satu tulisan Aloisius di bali.tribunnews.com (2018) pengamat ekonomi digital H.M Eko Budi Cahyono mengatakan dengan banyaknya digital nomad di Bali ekosistem digital juga akan makin kuat, adanya tren wisatwan digital nomad dan Canggu sebagai destinasi terfavorit bagi kaum digital nomad di dunia ini akan membentuk pasar wisatawan baru dimana stakeholders harus mulai menyediakan dan meningkatkan kebutuhan bagi kaum digital nomad seperti coworking space dan kecepatan internet tinggi di desa Tibubeneng, Canggu. Makimoto (2013) menyebutkan bahwa digital nomad adalah simbol gaya hidup baru dimana orang-orang dibebaskan dari keterbatasan waktu dan lokasi berkat kemajuan perangkat cerdas seluler dan jaringan komunikasi berkecepatan tinggi. Pada dasarnya letak perbedaan digital nomad dengan wisatawan lainya yaitu terletak pada cara mereka melakukan pekerjaan, dan dapat ditemui di coworking space selain dari itu digital nomad melakukan kegiatan wisata seperti turis lainya seperti mengunjungi atraksi wisata, menggunakan akomodasi pariwisata dan menggunakan transportasi yang ada di Desa Tibubeneng, Canggu. Coworking space adalah sebuah ruang bersama yang digunakan untuk melakukan pekerjaan dan bertujuan untuk memfasilitasi pertumbuhan dan perkembangan para startup atau freelancer dalam mengerjakan pekerjaannya (Delvianti, 2018).

Selain stakeholders kedatangan digital nomad membuat masyarakat lokal harus bersiap akan adanya tren digital nomad untuk meningkatan kesadaran untuk meningkatkan pengetahuan dan penggunaan komunikasi digital menggunakan internet untuk mendapatkan keuntungan ekonomi dengan bekerja sebagai driver transportasi online, dan berbagai jasa atau kerajinan yang dapat ditawarkan kepada digital nomad baik secara langsung maupun grup sosial media online seperti facebook. Dari ulasan yang telah dipaparkan diatas, maka peneliti akan melakukan penelitian yang berjudul persepsi dan motivasi digital nomad berwisata di Desa Tibubeneng, Canggu.

\section{METODE PENELITIAN}


Penelitian ini dilakukan di Desa Tibubeneng, Canggu, Kecamatan Kuta Utara. Terletak $13 \mathrm{~km}$ dari pusat kota Denpasar dan dapat ditempuh 40 menit menggunakan kendaraan bermotor. Pada tahun 2018 Canggu terpilih sebagai destinasi terfavorit bagi digital nomad di seluruh dunia (nomadlist.com). instrumen yang dilakukan pada penelitian adalah dengan menggunakan kuisioner sebanyak 140 yang akan di sebarkan kepada responden (digital nomad) yang berada di coworking space di Desa Tibubeneng, Canggu. Dalam kuisioner yang akan disebar terdapat tiga bagian pertanyaan yang harus diisi oleh responden yaitu karakteristik digital nomad yang ada di Desa Tibubeneng, Canggu yang menggunakan rujukan teori dari Seaton \& Bennet 1996 yang terdiri dari tourist descriptor dan trip descriptor, persepsi digital nomad terhadap Desa Tibubeneng, Canggu menggunakan rujukan teori dari James $\mathrm{J}$. Spilane 1987 tentang lima hal yang harus ada pada sebuah destinasi yaitu facilities, attraction, infrastructure, transportation, hospitality atau sering disingkat FAITH dan motivasi digital nomad dengan menggunakan rujukan teori dari Mc Intosh 1977 \& Murphy 1985 yang terdiri dari motivasi fisik, motivasi budaya, motivasi sosial, motivasi fantasi. Selain penyebaran kuisioner untuk mendapatkan data dalam penelitian ini dilakukan sebuah observasi, studi kepustakaan, dokumentasi dan wawancara terbuka. Data yang telah diperoleh akan diolah dengan mentabulasikan jawaban dari responden pada kuisioner yang diberikan kemudian akan diukur dengan skala likert, disajikan dalam sebuah tabel sederhana dan dipaparkan secara deksriptif.

\section{HASIL DAN PEMBAHASAN \\ Gambaran Umum Lokasi Penelitian}

Desa Tibubeneng, Canggu adalah sebuah desa yang mulai gemar di datangi oleh wisatawan yang datang ke Bali. Desa Tibubeneng, Canggu mempunyai beberapa daya tarik wisata yang memikat wisatawan untuk datang seperti Pantai Berawa dan Pantai Batu Bolong yang bisa dijadikan tempat untuk menghabiskan waktu luang atau melakukan kegiatan surfing. Selain daya tarik alam Desa Tibubeneng, Canggu memiliki atraksi kebudayaan khas Bali seperti bangunan khas Bali di sepanjang area Desa Tibubeneng,
Canggu seperti rumah masyarakat lokal dan tempat ibadah mereka yaitu pura, selain itu wisatawan dapat melihat upacara umat hindu Bali di hari tertentu. Untuk mencapai Desa Tibubeneng, Canggu wisatawan yang baru tiba di bandara I Gusti Ngurah Rai dapat menggunakan transportasi seperti taxi maupun sepeda motor. Jarak tempuh menuju Desa Tibubeneng, Canggu dari bandara yaitu sekitar 20 kilometer dan dapat ditempuh dalam waktu kurang lebih 1 jam.

\section{Karakteristik Digital Nomad di Desa Tibubeneng, Canggu}

Karakteristik digital nomad jika dilihat dari asal negara didapatkan hasil yang sangat bervariasi mulai dari Eropa, Australia, Amreika, Asia dan Afrika. Untuk melihat secara lebih detail mengenai data karakteristik digital nomad yang ada di Desa Tibubeneng, Canggu dapat dilihat pada penjabaran dibawah ini.

1. Berdasarkan asal negara digital nomad di Desa Tibubeneng, Canggu didominasi oleh digital nomad yang berasal dari Jerman dengan persentase 21,4\%, Australia 15\% dan Amerika Serikat $14,3 \%$ hal ini disebabkan karena ketiga negara tersebut adalah negara maju sehingga kemampuan untuk mengunjungi suatu destinasi baru menjadi relatif lebih mudah.

2. Berdasarkan jenis kelamin didominasi oleh laki-laki $51,4 \%$ dan perempuan $48,6 \%$ hal ini disebabkan laki-laki mempunyai tingkat aktivitas yang lebih tinggi dibandingkan perempuan untuk melakukan pekerjaan dan berwisata secara bersamaan.

3. Berdasarkan usia di dominasi oleh digital nomad dengan rentang usia 26 s/d 35 tahun dengan persentase $54,3 \%$ hal ini disebabkan pada usia tersebut adalah usia produktif dimana seseorang telah menyelesaikan pendidikan dan memulai komitmen baru dengan bekerja atau berbisnis.

4. Berdasarkan status perkawinan di dominasi oleh digital nomad yang lajang dengan peresntase $91,4 \%$ hal ini disebabkan karena mereka masih mempunyai komitmen dengan pekerjaan dan bisnis yang mereka jalani.

5. Berdasarkan tingkat pendidikan di dominasi oleh sarjana 49,3\%, magister $2,1 \%$, diploma $19,3 \%$, sma $7,1 \%$ dan 
doktor 2,2\%. Hal ini disebabkan sarjana adalah salah satu persyaratan yang harus diselesaikan oleh seseorang untuk mendapatkan pekerjaan.

6. Berdasarkan pekerjaan di dominasi oleh pengusaha $32,1 \%$, karyawan $27,2 \%$, pelajar $20,7 \%$ konten kreator $19,3 \%$ dan PNS 0,7\%. Hal ini disebabkan karena pengusaha mempunyai waktu yang fleksibel dan tidak terikat oleh aturan dari atasan.

7. Berdasarkan hobi di dominasi dengan travelling $37,9 \%$, olahraga $20 \%$, membaca $17,8 \%$, It dan teknologi $13,6 \%$ dan gaya hidup sehat $10,7 \%$. Hal ini disebabkan karena travelling adalah salah satu cara yang paling disukai oleh seseorang untuk melepaskan penat.

8. Berdasarkan akomodasi di dominasi dengan hostel $42,2 \%$, villa $24,3 \%$, homestay $21,4 \%$ dan hotel $12,1 \%$. Hal ini disebabkan karena hostel mempunyai harga sewa yang cukup terjangkau dan mendukung seseorang untuk berinteraksi dengan orang baru yang berada di hostel yang sama.

9. Berdasarkan lama tinggal di dominasi oleh digital nomad yang tinggal selama $>4$ minggu dengan persentase $32,1 \%$ hal ini disebabkan karena Desa Tibubeneng, Canggu mempunyai atraksi wisata yang menarik dan fasilitas penunjang pariwisata yang baik.

10. Berdasarkan uang yang dihabiskan, ratarata digital nomad menghabiskan uang dalam sehari adalah >\$50 dengann persentase $54,4 \%$, Adapaun uang yang dihabiskan dalam sehari adalah untuk membayar sewa hostel, sewa coworking space, akomodasi, transportasi dan makan dalam sehari. Hasil ini didukung oleh penelitian yang dilakukan oleh Tunjungsari (2018) bahwa mayoritas wisatawan di Canggu menghabiskan uang $\$ 50$ dalam sehari.

11. Berdasarkan teman perjalanan, digital nomad paling banyak berpergian sendiri dengan persentase $45 \%$, teman $32,2 \%$, pasangan dan keluarga $7,1 \%$. Hal ini disebabkan karena meraka cenderung akan memperoleh teman baru disuatu destinasi dan menambah teman baru.

12. Berdasarkan jenis transportasi di dominasi dengan menggunakan sepeda motor dengan persentase $87,9 \%$, taxi $10,7 \%$ dan mobil pribadi $1,4 \%$. Hal ini disebakan karena kemacetan dan jalanan Desa Tibubeneng, Canggu yang tidak terlalu besar.

13. Berdasarkan perencanaan berwisata digital nomad lebih memilih mengatur perjalanannya secara individu dengan memperoleh persentase sebesar 96,4\% sedangkan menggunakan usaha perjalanan wisata dengan persentase $3,6 \%$. Hal ini disebabkan karena mengatur kegiatan wisata secara individu lebih fleksibel dan tidak terikat oleh aturan dan waktu dari pihak lain.

\section{Persepsi Digital Nomad Terhadap Desa Tibubeneng, Canggu}

Untuk mengetahui bagaimana persepsi digital nomad di Desa Tibubeneng, Canggu akan dipaparkan data dan pembahasan menggunakan teori FAITH (facilities, attraction, infrastructure, transportation, hospitality) dari James J Spilalane dan diukur menggunakan skala likert, pada variabel ini akan di ungkap bagaimana kondisi Desa Tibubeneng, Canggu sebagai destinasi terfavorit digital nomad di dunia menggunakan indikator yang telah disebutkan diatas.

Tabel 2. Nilai Rata - Rata Indikator Persepsi

\begin{tabular}{|c|c|c|c|}
\hline Indikator & Pernyataan & Nilai & Keterangan \\
\hline \multirow[t]{3}{*}{ Facilities } & $\begin{array}{l}\text { Kualitas } \\
\text { coworking } \\
\text { sapace }\end{array}$ & 4,3 & \multirow{3}{*}{ BAIK } \\
\hline & $\begin{array}{l}\text { Kualitas } \\
\text { akomodasi }\end{array}$ & 4,5 & \\
\hline & $\begin{array}{l}\text { Kualitas } \\
\text { Tourist } \\
\text { information } \\
\text { Centre }\end{array}$ & 3,7 & \\
\hline \multirow[t]{3}{*}{ Attraction } & Kualitas pantai & 4,3 & \multirow[t]{2}{*}{ BAIK } \\
\hline & $\begin{array}{l}\text { Kualitas } \\
\text { Upacara } \\
\text { Keagamaan }\end{array}$ & 3,6 & \\
\hline & $\begin{array}{l}\begin{array}{l}\text { Kualitas } \\
\text { skatepark }\end{array} \\
\end{array}$ & 3,3 & \\
\hline \multirow[t]{4}{*}{ Infrastructure } & $\begin{array}{l}\text { Kualitas } \\
\text { Internet }\end{array}$ & 4,1 & \multirow{4}{*}{ BAIK } \\
\hline & $\begin{array}{l}\text { Kualitas } \\
\text { ketersediaan } \\
\text { listrik } \\
\end{array}$ & 4,2 & \\
\hline & Kualitas air & 4,2 & \\
\hline & $\begin{array}{l}\text { Kualitas } \\
\text { kondisi jalan }\end{array}$ & 3,1 & \\
\hline Transportation & $\begin{array}{l}\text { Kualitas } \\
\text { transportasi } \\
\text { umum }\end{array}$ & 3,7 & \\
\hline
\end{tabular}




\begin{tabular}{|c|c|c|c|}
\hline & $\begin{array}{l}\text { Kualitas } \\
\text { transportasi } \\
\text { online } \\
\end{array}$ & 4,1 & BAIK \\
\hline & $\begin{array}{l}\text { Kualitas harga } \\
\text { sewa } \\
\text { kendaraan } \\
\text { pribadi }\end{array}$ & 4,2 & \\
\hline \multirow[t]{3}{*}{ Hospitality } & $\begin{array}{ll}\text { Hospitality } & \\
\text { karyawan } \\
\text { akomodasi }\end{array}$ di & 4,3 & \multirow{3}{*}{$\begin{array}{c}\text { SANGAT } \\
\text { BAIK }\end{array}$} \\
\hline & $\begin{array}{l}\text { Hospitality } \\
\text { masyarakat } \\
\text { lokal }\end{array}$ & 4,2 & \\
\hline & $\begin{array}{l}\text { Hospitality } \\
\text { karyawan } \\
\text { coworking } \\
\text { space }\end{array}$ & 4,3 & \\
\hline
\end{tabular}

Sumber: Hasil Penelitian, 2019.

Berdasarkan tabel 2 dapat dilihat bahwa indikator yang mendapatkan respon paling baik dari digital nomad adalah indikator hospitality dengan total rata - rata 4,26 yang berarti sangat baik dalam ukuran skala likert, hal ini di sebabkan karena budaya ramah tamah yang di miliki oleh masyarakat Indonesia khususnya di Desa Canggu di aplikasikan secara langsung dalam industri hospitality dengan standar pelayanan yang baik kepada wisatawan dan digital nomad selain itu data diatas di dukung dengan hasil penelitian sebelumnya yang dilakukan oleh Agirachman (2016) yang mendapatkan hasil bahwa coworking space merupakan tempat yang paling nyaman untuk bekerja bagi digital nomad dilihat dari fasilitas dan pelayanan staf yang ada. Selain itu data diatas di dukung dengan ulasan yang diberikan wisatawan mancanegara pada TripAdvisor.com sebagai berikut: "matra coworking adalah tempat yang bagus, koneksi yang kuat, teman baru dan resepsionis yang ramah" (Kav, Moscow, Rusia pada tanggal 10 September 2019). Sedangkan indikator yang mendapatkan respon terendah dari digital nomad adalah indikator attraction dengan total rata - rata 3,7 yang berarti baik dalam ukuran skala likert, walaupun mendapatkan total rata - rata terendah indikator ini mendapat respon baik dari digital nomad hal ini di dukung oleh hasil observasi yang dilakukan selama melakukan penelitian bahwa transportasi yang digunankan para digital nomad selalu dilengkapi dengan papan surfing yang mengindikasikan bahwa mereka pergi ke pantai dan melakukan surfing. Selain observasi data diatas juga didukung oleh hasil penelitian yang dilakukan oleh Tunjungsari (2018) yang mendapatkan hasil bahwa wisatawan yang berkunjung ke Canggu lebih banyak melakukan aktivitas di pantai.

\section{Motivasi Digital Nomad Berwisata di Desa Tibubeneng, Canggu}

Untuk mengetahui motivasi digital nomad berwisata di Desa Tibubeneng, Canggu maka akan dipaparkan hasil data yang diperoleh menggunakan teori dari MC Intosh yang terdiri dari motivasi fisik, motivasi budaya, motivasi sosial dan motivasi fantasi, melalui indikator tersebut akan dipaparkan bagaimana digital nomad melakukan kegiatan berwisata selama berada di Desa Tibubeneng, Canggu. Data yang diperoleh terkait motivasi dapat dilihat pada tabel 3 .

Tabel 4. Nilai Rata -Rata Indikator Motivasi

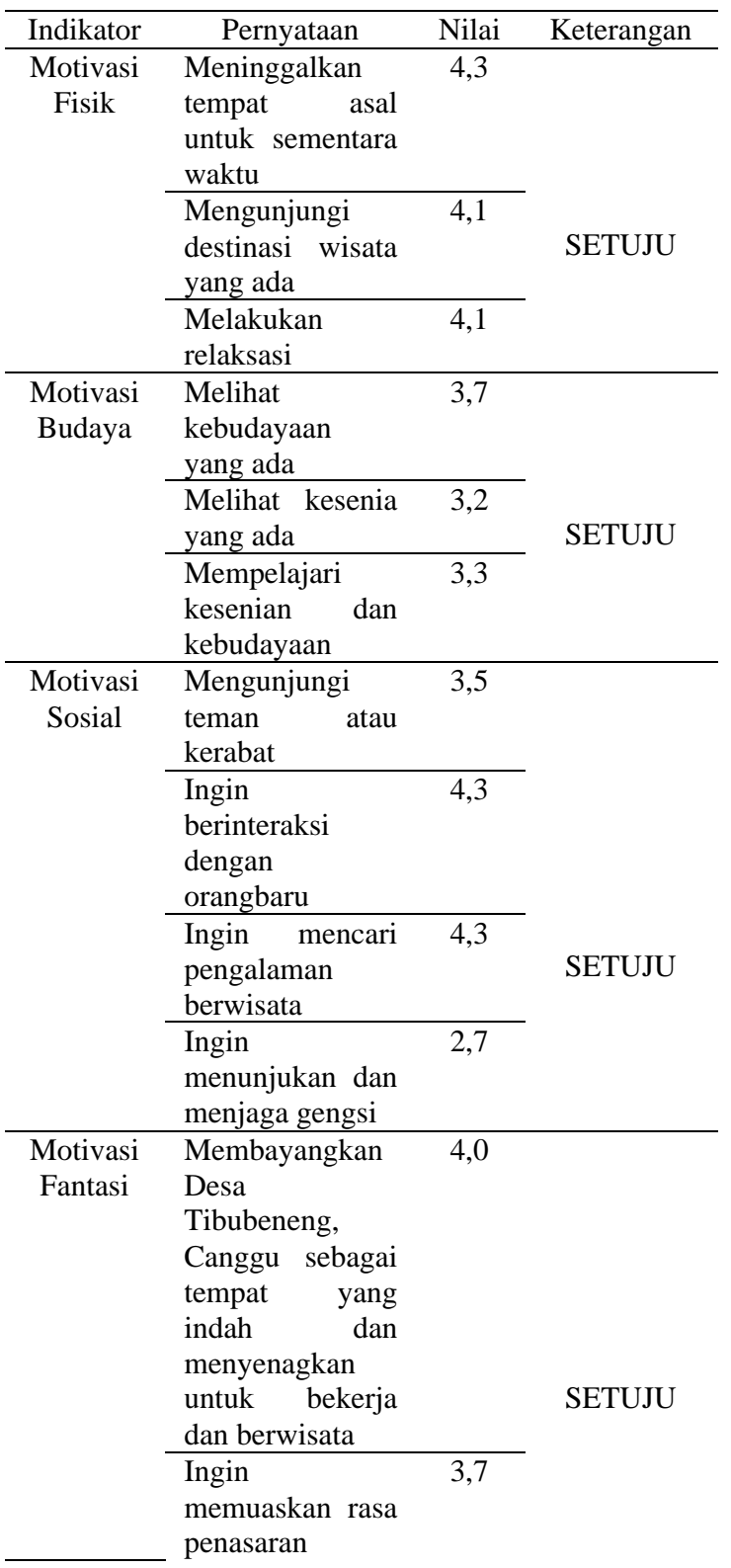


Sumber: Hasil Penelitian, 2019.

Berdasarkan tabel 4.43 di atas dapat di ketahui bahwa indikator yang mempunyai nilai rata - rata paling tinggi adalah motivasi fisik yaitu sebesar 4,16 yang berarti digital nomad setuju terhadap pernyataan terkait motivasi fisik yang membuat mereka memutuskan untuk berkunjung ke Desa Tibubeneng, Canggu. Data diatas di dukung oleh hasil penelitian yang dilakukan oleh Suwena \& Suardana (2016) yang mendapatkan hasil bahwa menjauhkan diri dari lingkungan sehari-hari, untuk lepas dari pekerjaan dan menghilangkan stress dan ketegangan adalah faktor pendorong bagi wisatawan datang ke Bali selain itu kondisi dilapangan memperlihatkan bahwa Canggu mempunyai daya tarik wisata yang menarik untuk di kunjungi seperti Pantai Berawa dan Pantai Batu Bolong. Sedangkan indikator yang mendapatkan nilai rata - rata terendah dari digital nomad adalah indikator motivasi budaya dengan nilai rata - rata sebesar 3,4. Walaupun mendapatkan nilai rata - rata terendah indikator motivasi budaya tetap menjadi salah satu alasan digital nomad berkunjung ke Desa Tibubeneng, hal ini didukung oleh pernyataan salah satu digital nomad yang berasal dari Amerika Serikat yaitu Vivian (2019) yang mengatakan bahwa "salah satu keunikan Canggu yaitu tentang masyarakat lokal yang selalu melakukan sembahyang setiap hari. Saya melihatnya di hostel tempat saya tinggal, di jalan dan hampir seluruh tempat yang saya datangi saya selalu melihat hal yang sama" (Wawancara, 15/08/09).

Dari data dan hasil wawancara yang diperoleh budaya masih menjadi salah satu daya tarik digital nomad untuk datang ke Desa Tibubeneng, Canggu. Sebagai destinasi terfavorit bagi kalangan digital nomad informasi mengenai Desa Tibubeneng, Canggu sangat mudah ditemukan melalui platform media online mulai dari informasi mengenai atraksi yang ada, budaya, dan informasi lainnya mengenai Desa Tibubeneng, Canggu hal ini didukung oleh hasil penelitian yang dilakukan oleh Negara \& Sagitha (2018) yang mendapatkan hasil bahwa kepercayaan terhadap informasi yang tersedia secara online menjadi sangat penting bagi wisatawan guna mengambil keputusan perjalanan wisata, hasil penelitian tersebut memiliki korelasi dengan penelitian yang dilakukan sekarang dimana para digital nomad yang bergelut dengan platform media online cenderung mendapatkan segala informasi melalui media online.

\section{SIMPULAN DAN SARAN Simpulan}

Karakteristik digital nomad di Desa Tibubeneng, Canggu mayoritas berasal dari Eropa dan Australia. Digital nomad yang berwisata di Desa Tibubeneng, Canggu di dominasi oleh wisatawan pria dengan rentang usia 26-35 tahun yang telah menamatkan pendidikan di strata satu sarjana dan berprofesi sebagai pengusaha. Mereka memiliki hobi traveling dan memilih untuk tinggal di hostel selama lebih dari 4 minggu di Desa Tibubeneng, Canggu, untuk melakukan kegiatan wisatanya digital nomad lebih tertarik mengatur perjalanan sendiri dan menggunakan sepeda motor untuk beraktivitas.

Persepsi digital nomad terhadap Desa Tibubeneng, Canggu dilihat dari segi fasilitas sudah baik dengan total nilai rata - rata 4,16. Pernyataan yang mendapatkan nilai rata - rata paling tinggi adalah ketersediaan akomodasi dengan nilai rata - rata sebesar 4,5 kemudian adanya beberapa pilihan coworking space mendapat nilai rata - rata sebesar 4,3 dan keberadaan tourist information centre sebesar 3,7 . Dilihat dari atraksi wisata total nilai rata rata yang diperoleh adalah sebesar 3,7 yang berarti baik. Digital nomad paling menyukai atraksi wisata alam berupa pantai untuk melakukan surfing dan bersantai di Pantai Berawa dan Pantai Batu Bolong dengan nilai rata - rata sebesar 4,2 kemudian menemukan dan melihat upacara khas Bali dengan nilai rata - rata 3,6 dan pilihan skatepark dengan nilai 3,3. Infrastruktur mendapatkan total nilai ratarata sebesar 3,9 yang berarti baik, adapun nilai infrastruktur pendukung seperti internet mendapat nilai 4,1 , air mendapatkan nilai 4,2 , dan listrik mendapatkan nilai 4,2 terbilang sudah baik namun kondisi jalan di Desa Tibubeneng, Canggu harus diperbaiki dengan mendapat nilai terendah dalam indikator ini yaitu 3,1. Transportasi di Desa Tibubeneng, Canggu sudah baik dengan mendapatkan total nilai rata - rata sebesar 4 seperti adanya transportasi online yang digemari seperti Gojek dan Grab sangat membantu mereka mendapat nilai rata - rata 4,1 , kemudian harga sewa sepeda motor dan mobil serta dengan nilai 4,2 dan adanya taxi sebagai transportasi umum 
dengan nilai 3,7. Kemudian Hospitality yang ada di Desa Tibubeneng, Canggu meliputi hospitality karyawan di coworking space dengan nilai 4,3, hospitality karyawan di akomodasi dengan nilai 4,3 dan masyarakat lokal terhadap digital nomad dengan nilai 4,2 adalah indiktaor yang mendapatkan total nilai rata - rata tertinggi yaitu sebesar 4,26 yang berarti secara keseluruhan mendapatkan respon yang baik dari digital nomad.

Motivasi berwisata digital nomad ke Desa Tibubeneng, Canggu dilihat dari motivasi fisik dengan total nilai rata - rata 4,16 adalah indikator dengan nilai tertinggi dari responden. Alasan paling kuat mereka adalah unutk meninggalkan tempat asal untuk sementara waktu dengan nilai 4,3. Motivasi budaya dengan total nilai rata-rata 3,4 yang berarti setuju. Pernyataan yang paling membuat mereka berwisata yaitu untuk melihat kebudayaan yang ada di Desa Tibubeneng, Canggu dengan nilai 3,7. Motivasi sosial mendapatkan total nilai rata - rata 3,7. Pernyaatan yang paling kuat menjadi alasan mereka datang ke Desa Tibubeneng Canggu adalah untuk bertemu dan berinteraksi dengan orang baru dengan nilai 4,3 serta mendapatkan pengalaman berwisata baru di Desa Tibubeneng, Canggu dengan nilai 4,3, sedangkan motivasi untuk menunjukan gengsi bukanlah alasan bagi mereka datang ke Desa Tibubeneng, Canggu dengan mendapatkan nilai terendah yaitu 2,7. Motivasi fantasi mendapatkan total nilai rata - rata sebesar 3,85. Pernyataan yang membuat mereka datang adalah karena membayangkan Desa Tibubeneng, Canggu sebagi tempat yang indah dan menyenangkan untuk berwisata dan kerja dengan nilai 4,0 dan memuaskan rasa penasaran dengan nilai 3,7 .

\section{Saran}

Melihat peluang Desa Tibubeneng, Canggu sebagai destinasi terbaik untuk digital nomad didunia, maka pengusaha harus menyiapkan dan meningkatkan fasilitas pendukung kegiatan mereka seperti menyediakan dan meningkatkan kualitas coworking space, menyediakan akomodasi yang lebih baik entah penginapan ataupun restoran, menyediakan tempat penyewaan kendaraan pribadi, dan berbagai kebutuhan untuk digital nomad lainya.

Melihat Desa Tibubeneng, Canggu sebagai destinasi favorit bagi digital nomad pemerintah harus memperbaiki kondisi jalan yang ada di Desa Tibubeneng, Canggu, meningkatkan infrastruktur pendukung seperti jaringan internet selalu dalam kondisi yang prima diseluruh area Desa Tibubeneng, Canggu dan memambah tower pemancar internet. Kemudian memastikan supply air dan aliran listrik terpenuhi sepanjang tahun tanpa adanya hambatan.

Untuk penelitian selanjutnya dapat mengembangkan kepuasan di coworking space yang ada di Desa Tibubeneng, Canggu dan melihat persepsi digital nomad terhadap coworking space yang lebih spesifik serta kualitas pelayanan di coworking space. 


\section{Kepustakaan}

Agirachman, Fauzan \& Putra, Gierlang. 2016. Urban Coworking Space: Creative Tourism in Digital Nomads Perspective. Arte-Polis 6 International Conference Imagining Experiences: Creative Tourism and the Making of Place, Bandung 4-5 August 2016, Volume 2.

Aloisius. 2018. https://bali.tribunnews.com. Diakses pada tanggal 18 Juni 2019 pukul 23.07 WITA

Delvianti, Ella. Maulida, Ully. \& Asyarsinyo, Doddy. 2018. Re-Desain Co-working Space Bandung Digital Valley. eProceeding of Art \& Design: Vol.5, No.1 Maret 2018

Dinas Pariwisata Provinsi Bali. 2018. Jumlah Kunjungan Wisatawan Mancanegara Ke Bali. www.disparda.baliprov.go.id diakses tanggal 1 November 2018.

Harsono \& Yusrizal. (2017). Motivasi Wisatawan Mengunjungi Objek Wisata Di Desa Pawan Kabupaten Rokan Hulu. Jom FISIP Volume 4 No.1 Februari 2017.

Makimoto, Tsugio. (2013). The Age of the Digital Nomad: Impact of CMOS Innovation. Appeared in IEEE Solid State Circuits, Vol.5, No.1, PP.40-47 (Winter, 2013).

McIntosh, Robert W., Charles R Goeldner, dan J.R Brent Ritjie. 1995. Tourism: Principle, Practices, Philosophies. (Seventh Edition). New York: John Wiley dan Sons, Inc.

Sagita. Wikanatha \& Negara. Kusuma. 2018. Kapabilitas Praktis Domain Perjalanan Wisata Bali: Aplikasi Perjalanan Wisata Berbasis Ponsel Cerdas. Jurnal IPTA Vol.6 No.1, 2018.

Seaton, A.V \& M.M. Bennet. 1996. The Marketing of Tourism Product: Concepts, Issues, and Cases. London: International Business Press.
Suwena, I Ketut \& Suardana. 2016. Faktor Pendorong dan Penarik Wisatawan Backpacker Mancanegara Berwisata ke Bali. Jurnal IPTA Vol.4 No.2, 2016.

Tunungsari, Ratih. 2018. Karakteristik dan Persepsi Wisatawan Mancanegara di Kawasan Sanur dan Canggu, Bali. Jurnal Pariwisata Terapan, No.2, Vol.2, 2018.

https://nomadlist.com di akses pada tanggal 30 April 2019 pukul 9.46 WITA 